\title{
Natural Compounds with Aromatase Inhibitory Activity: An Update
}

Authors

Affiliations
Marcy J. Balunas ${ }^{1,2,3,4}$, A. Douglas Kinghorn ${ }^{5}$

The affiliations are listed at the end of the article
Key words

- breast cancer

- aromatase

- natural compounds

- plants

- marine organisms

- fungi received February 3, 2010

revised May 28, 2010

accepted July 2, 2010

Bibliography

Dol http://dx.doi.org/

10.1055/s-0030-1250169

Published online July 15, 2010

Planta Med 2010; 76:

1087-1093 @ Georg Thieme

Verlag KG Stuttgart · New York .

ISSN 0032-0943

\section{Correspondence}

\section{Dr. Marcy J. Balunas}

Division of Medicinal Chemistry,

Department of Pharmaceutical

Sciences

School of Pharmacy

69 North Eagleville Road,

Unit 3092

Storrs, CT 06269

USA

Phone: + 18604864066

Fax: + 18604865792

marcy.balunas@uconn.edu

\section{Abstract}

$\nabla$

Several synthetic aromatase inhibitors are currently in clinical use for the treatment of postmenopausal women with hormone-receptor positive breast cancer. However, these treatments may lead to untoward side effects and so the search for new aromatase inhibitors continues, especially those for which the activity is pro-

\section{Introduction}

\section{$\nabla$}

Breast cancer is one of the leading causes of death in women in developed countries and is a growing public health concern in developing countries as well $[1,2]$. Estrogens and the estrogen receptor are widely known to play an important role in breast cancer development and progression. Aromatase, a CYP19 enzyme, is the rate-limiting enzyme in the conversion of testosterone and androstenediol to the estrogens, estrone and estradiol. Aromatase inhibitors (AIs) have been shown to significantly reduce, and in most cases eliminate, the production of estrogens in postmenopausal women.

Aromatase inhibitors have shown a considerable clinical impact on the development and progression of breast cancer [3]. A recent study by the Cochrane Collaboration compared AIs with non-AI treatments of primary breast cancer, as well as comparing AIs to each other using data from 37 clinical trials [4]. It was found that AIs were advantageous over other types of endocrine therapies (e.g., tamoxifen), with the three clinically available AIs (anastrazole, exemestane, and letrozole) showing similar benefits on patient survival. The Cochrane Collaboration report also discussed the toxicity profiles of AIs in comparison with other types of endocrine therapies and found that AIs resulted in an increase of rash, diarrhea, and vomiting but a decrease in vaginal bleeding and moter-specific, targeting the breast-specific promoters I.3 and II. Recently, numerous natural compounds have been found to inhibit aromatase in noncellular, cellular, and in vivo studies. These investigations, covering the last two years, as well as additional studies that have focused on the evaluation of natural compounds as promoterspecific aromatase inhibitors or as aromatase inducers, are described in this review.

thromboembolism. Overall, the study found that AIs provided an increased survival benefit over other endocrine therapies, with acceptable toxicity profiles. Many physicians have begun prescribing AIs as a first-line treatment in postmenopausal breast cancer patients [3].

So if there are already clinically available AIs, why search for additional compounds that inhibit aromatase, inclusive of natural products? AIs do have several side effects, such as those listed above, but also lead to more severe side effects including effects on the bones, brain, and heart $[5,6]$. Natural products with a long history of use, such as those from foods or from traditional medicines, that also exhibit aromatase inhibitory activity, may have less associated toxicity. Furthermore, natural compounds might help in the search for promoter-specific AIs, a new direction in AI research, and thus selectively target aromatase in the breast and reduce systemic toxicity.

This review summarizes the most recent advances in the search for natural product aromatase inhibitors. We focus primarily on natural compounds that have been reported in the two year period (February 2008 - January 2010) since the publication of our previous comprehensive review of natural product AIs that covered all of the relevant literature up to January 2008 [7]. Discussion of active compounds is organized based on aromatase activity in enzyme versus cellular and in vivo bioassays since the level of information provided by 
these types of assays can be drastically different. These more recent accounts will then be compared with the most potently active natural product AIs summarized in our previous review [7], followed by a discussion of the current research trends in AI research and future directions for natural product AIs.

\section{Natural Products Active against Aromatase \\ $\nabla$}

Since January 2008, 31 natural product compounds have been reported with aromatase inhibitory activity ( Tables 1, 2 and Figs. 1, 2). For the purpose of this review, activity will be defined as follows: in noncellular assays, strongly active compounds are those with $\mathrm{IC}_{50}$ values of $<5 \mu \mathrm{M}$, moderately active substances having $\mathrm{IC}_{50}$ values in the range of $>5-10 \mu \mathrm{M}$, and weakly active compounds with $\mathrm{IC}_{50}$ values of $>11-25 \mu \mathrm{M}$. In cellular assays, "strongly active" refers to compounds with an $\mathrm{IC}_{50}$ value of $<10 \mu \mathrm{M}$, "moderately active", $\mathrm{IC}_{50}>10-20 \mu \mathrm{M}$, and "weakly active", $\mathrm{IC}_{50}>20-50 \mu \mathrm{M}$. Not all reports have included an $\mathrm{IC}_{50}$ value and these will be treated on an individual basis. Compounds are numbered according to their position in the tables, where they are organized based on compound class. In the text, compounds are discussed based on their levels of activity with the most active compounds discussed first followed in decreasing order of activity.

\section{Compounds active in noncellular Al assays}

In noncellular testing, 24 active AI natural compounds were reported during the past two years. As in the previous review of natural product AIs, flavonoids were the most commonly reported class of active compounds found in noncellular assays (12 in total including six flavones, three flavanones, one biflavanone, one chalcone, one isoflavone), with active compounds also found among the xanthone (3), chromanone (2), fatty acid (2), terpenoid (2), alkaloid (1), coumarin (1), and depsidone (1) classes ( Table 1, Fig. 1 ).

These compounds were isolated mainly from terrestrial plants, including several from botanical dietary supplements (phytomedicines), with one report of AIs from marine fungi and the isolation of an active AI from a terrestrial endophytic fungus. Other compounds found to inhibit aromatase were commercially purchased but are commonly found from natural source organisms. Several types of noncellular assays were utilized for screening these natural product AIs. The most commonly reported assay system was the radiometric tritiated water release assay using microsomes from different sources, typically from human placentas, although one report utilized microsomes from HepG2 cell lysate [8] and two other reports used commercially available Supersomes ${ }^{\circledR}[9,10]$. The other type of noncellular AI assay involved the use of a fluorometric substrate [either 0 -benzylfluorescein benzyl ester (DBF) or 7-methyoxy-4-trifluoromethylcoumarin (MFC)] with purified aromatase enzyme. Because the radiometric and fluorometric assays are not readily comparable, the results from each type of assay will be discussed separately.

In the radiometric assays, the most active natural product compounds were two terpenoids isolated from Commiphora myrrha (myrrh) ( Table 1, Fig. 1) [11]. Thus, 2-methoxy-5-acetoxyfuranogermacr-1(10)-en-6-one (20) and dehydroabietic acid (21) were both found to have $\mathrm{AI} \mathrm{IC}_{50}$ values in the high nanomolar range (210 nM and $320 \mathrm{nM}$, respectively). However, compound 21 was also found to inhibit the growth of HUVEC (human umbilical vein epithelial) cells with an $\mathrm{IC}_{50}$ of $69 \mathrm{~nm}$, indicating a strong

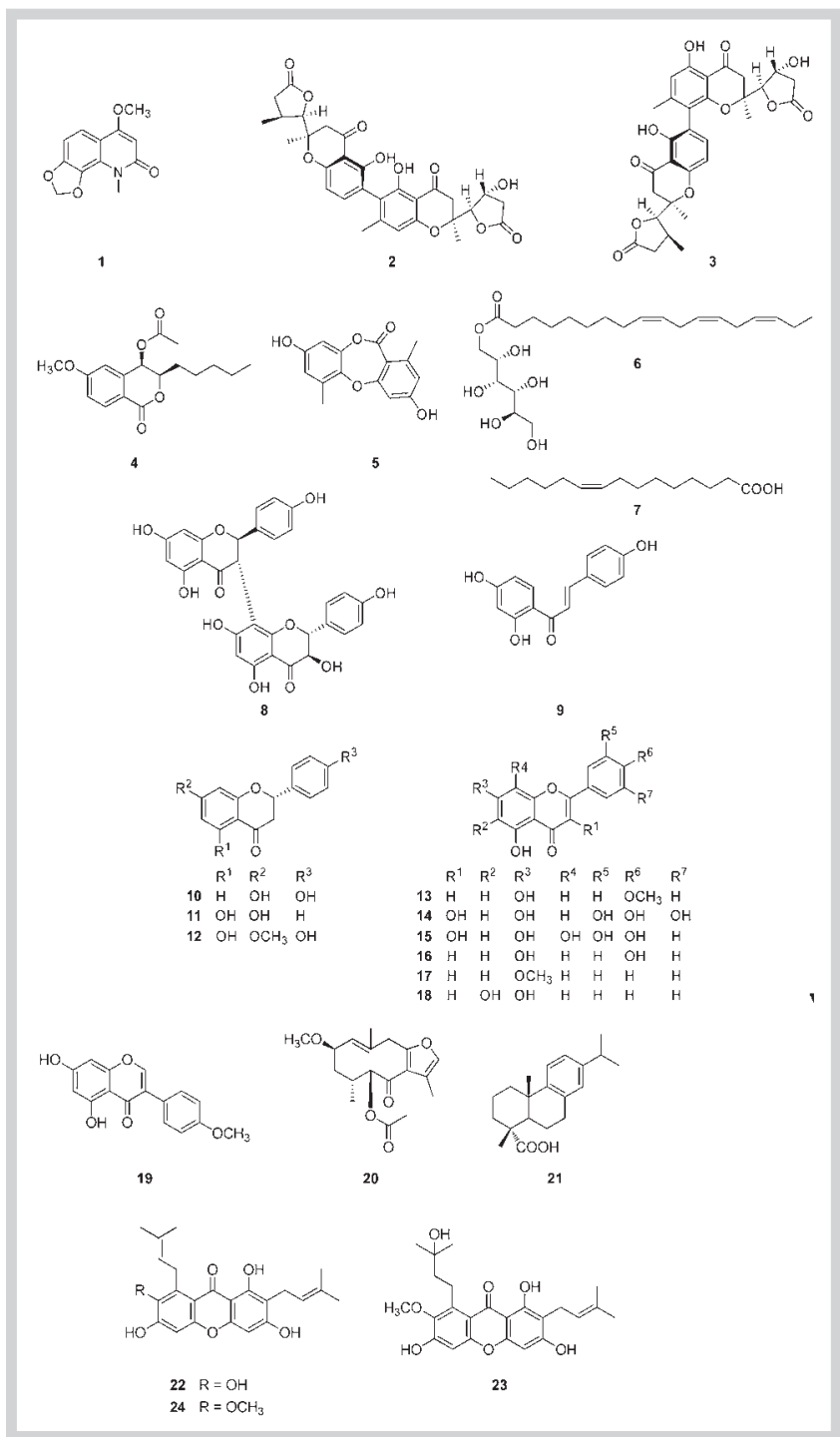

Fig. 1 Chemical structures of compounds 1-24.

cytotoxicity by this substance, which would most likely prohibit its further preclinical development as an AI. These compounds were further tested using an in vitro uterine contraction assay and found to be inactive.

Several other natural compounds were also found to be active in the noncellular radiometric assay ( $\bullet$ Table 1 ). Isoliquiritigenin (9), typically isolated from the botanical dietary supplement Glycyrrhiza glabra (licorice), was tested against a recombinant enzyme system involving human CYP19 Supersomes ${ }^{\circledR}$ and found to be strongly active with an $\mathrm{AI}^{\mathrm{IC}} \mathrm{C}_{50}$ of $3.8 \mu \mathrm{M}$ [9]. In work carried out at The Ohio State University, three xanthones isolated from the widely-utilized botanical dietary supplement Garcinia mangostana (mangosteen), were found to be active in this assay, including the moderately active garcinone $\mathrm{D}\left(23, \mathrm{IC}_{50} 5.2 \mu \mathrm{M}\right)$ and $\gamma$-mangostin $\left(22, \mathrm{IC}_{50} 6.9 \mu \mathrm{M}\right)$, and the weakly active $\alpha$-mangos$\operatorname{tin}\left(\mathbf{2 4}, \mathrm{IC}_{50} 20.7 \mu \mathrm{M}\right)$ [12]. These mangosteen xanthones were also tested in cellular AI assays and found to have varying levels of activity, as reported in the next section.

Two fatty acids, 9Z,12Z,15Z-octadecatrienoic acid sorbitol ester (6) [13], and linoleic acid (7) [14], were also found to be active in the noncellular radiometric AI assay. However, as previously re- 
Table 1 Natural compounds active against aromatase in noncellular assays ${ }^{\mathrm{a}}$.

\begin{tabular}{|c|c|c|c|c|c|}
\hline \multirow{2}{*}{$\begin{array}{l}\text { Compound Code } \\
\text { Alkaloid }\end{array}$} & \multirow[t]{2}{*}{ Source } & \multirow[t]{2}{*}{ Assay Type } & \multicolumn{2}{|c|}{ Activity } & \multirow[t]{2}{*}{ Ref. } \\
\hline & & & & & \\
\hline 1 & Casimiroa edulis & DBF enzyme $e^{b}$ & 3.92 & $\mu \mathrm{MIC} \mathrm{I}_{50}$ & [19] \\
\hline \multicolumn{6}{|l|}{ Chromanones } \\
\hline 2 & Monodictys putredinis & DBF enzyme ${ }^{b}$ & 16.5 & $\mu \mathrm{MIC} C_{50}$ & [23] \\
\hline 3 & Monodictys putredinis & DBF enzyme ${ }^{b}$ & 24.4 & $\mu \mathrm{MIC}_{50}$ & [23] \\
\hline \multicolumn{6}{|l|}{ Coumarin } \\
\hline 4 & Xyris pterygoblephara & DBF enzyme $e^{b}$ & 1.6 & $\mu \mathrm{MIC}_{50}$ & [17] \\
\hline \multicolumn{6}{|l|}{ Depsidone } \\
\hline 5 & Corynespora cassiicola L36 & MFC enzyme ${ }^{c}$ & 5.30 & $\mu \mathrm{MIC} C_{50}$ & [21] \\
\hline \multicolumn{6}{|l|}{ Fatty Acids } \\
\hline 6 & Brassica campestris & microsomes & 7.80 & $\mu \mathrm{g} / \mathrm{mL} \mathrm{IC}_{50}$ & [13] \\
\hline 7 & Brassaiopsis glomerulata & microsomes & 7.4 & PCA at $20 \mu \mathrm{g} / \mathrm{mL}$ & [14] \\
\hline \multicolumn{6}{|l|}{ Flavonoids } \\
\hline \multicolumn{6}{|l|}{ Biflavanone } \\
\hline 8 & Garcinia kola & DBF enzyme ${ }^{b}$ & 11.3 & $\mu \mathrm{MIC}_{50}$ & [22] \\
\hline \multicolumn{6}{|l|}{ Chalcone } \\
\hline 9 & Glycyrrhiza glabrad & Supersomes ${ }^{\circledR}$ & 3.8 & $\mu \mathrm{MIC}_{50}$ & [9] \\
\hline \multicolumn{6}{|l|}{ Flavanones } \\
\hline 10 & commerciald $^{\mathrm{d}}$ & MFC enzyme ${ }^{c}$ & 0.34 & $\mu \mathrm{MIC}_{50}$ & [16] \\
\hline 11 & Turnera diffusa & HepG2 cell lysate & 18.7 & $\mu \mathrm{MIC}$ & [8] \\
\hline 12 & Prunus avium & DBF enzyme ${ }^{b}$ & 1.2 & $\mu \mathrm{M} K_{i}$ & [20] \\
\hline \multicolumn{6}{|l|}{ Flavones } \\
\hline 13 & Turnera diffusa & HepG2 cell lysate & 10.8 & $\mu \mathrm{MIC} C_{50}$ & [8] \\
\hline 14 & commerciald $^{\mathrm{d}}$ & MFC enzyme ${ }^{c}$ & 10 & $\mu \mathrm{MIC} \mathrm{C}_{50}$ & [16] \\
\hline 15 & commerciald $^{\mathrm{d}}$ & MFC enzyme ${ }^{c}$ & 11 & $\mu \mathrm{MIC}$ & [16] \\
\hline 16 & commercial $^{d}$ & DBF enzyme ${ }^{b}$ & 1.0 & $\mu \mathrm{M} K_{i}$ & [20] \\
\hline 17 & Prunus avium & DBF enzyme $\mathrm{b}^{\mathrm{b}}$ & 2.1 & $\mu \mathrm{M} K_{i}$ & [20] \\
\hline 18 & commercial $^{d}$ & DBF enzyme ${ }^{b}$ & 5.1 & $\mu \mathrm{M} K_{i}$ & [20] \\
\hline \multicolumn{6}{|l|}{ Isoflavone } \\
\hline 19 & Trifolium pratense $e^{d}$ & Supersomes ${ }^{\circledR}$ & 12.5 & $\mu \mathrm{MIC} C_{50}$ & [10] \\
\hline \multicolumn{6}{|l|}{ Terpenoids } \\
\hline 20 & Commiphora myrrha & microsomes & 0.21 & $\mu \mathrm{MIC}_{50}$ & [11] \\
\hline 21 & Commiphora myrrha & microsomes & 0.32 & $\mu \mathrm{MIC}_{50}$ & [11] \\
\hline \multicolumn{6}{|l|}{ Xanthones } \\
\hline 22 & Garcinia mangostana & microsomes & 6.9 & $\mu \mathrm{MIC}_{50}$ & [12] \\
\hline 23 & Garcinia mangostana & microsomes & 5.2 & $\mu \mathrm{MIC}_{50}$ & [12] \\
\hline 24 & Garcinia mangostana & microsomes & 20.7 & $\mu \mathrm{MIC} \mathrm{C}_{50}$ & [12] \\
\hline
\end{tabular}

a The structures of compounds 1-24 are shown in 1 Fig. 1; ${ }^{\mathrm{b}}$ DBF (O-benzylfluorescein benzyl ester) was used as substrate with purified aromatase enzyme; ${ }^{\mathrm{c}}$ MFC (7-methoxy-4trifluoromethyl coumarin) was used as substrate with purified aromatase enzyme; ${ }^{\mathrm{d}}$ The source of the material in the literature reference was listed as commercial, but this compound is traditionally isolated from a natural product source

ported [15], unsaturated fatty acids have been shown to be interference compounds in non-cellular AI assays since they do not generally show activity in cellular AI screens. Another active AI natural product, the isoflavone biochanin $A$ [19, purchased commercially but typically isolated from Trifolium pratense (red clover)], was tested using the same recombinant enzyme system using human CYP19 Supersomes ${ }^{\circledR}$ as mentioned above, resulting in weak activity with an $\mathrm{AI}^{\mathrm{IC}} \mathrm{C}_{50}$ of $12.5 \mu \mathrm{M}$ [10]. Finally, using HepG2 cell lysate as the source of aromatase for their radiometric AI assay, Zhao and associates [8] isolated two compounds from Turnera diffusa (damiana), a plant which is purported to have aphrodisiac properties. They reported that the known flavonoids acacetin (13) and pinocembrin (11) exhibited $\mathrm{AI}^{\mathrm{IC}} \mathrm{C}_{50}$ values of 10.8 and $18.7 \mu \mathrm{M}$, respectively, causing them both to fall into the "weakly active" category, as delineated in this review.

In the noncellular fluorometric AI assays, the most active natural product reported in the last two years has been a commercially obtained sample of the licorice flavonoid, liquiritigenin $\left(\mathbf{1 0}, \mathrm{IC}_{50}\right.$ $340 \mathrm{nM},[16])$, using MFC as a substrate. This compound was initially found to be active using a molecular modeling program that simulated the docking of the ligands in the active site of the aromatase enzyme. The investigators then evaluated their modeling hits using an in vitro fluorometric AI assay. Liquiritigenin (10) was the most active of the three hypothetical AI compounds tested, with myricetin $\left(\mathbf{1 4}, \mathrm{IC}_{50} 10 \mu \mathrm{M}\right)$ and gossypetin $\left(\mathbf{1 5}, \mathrm{IC}_{50}\right.$ $11 \mu \mathrm{M}$ ) being found to have more moderate or weak AI activity. Another strongly active compound in the fluorometric assay was the dihydroisocoumarin, $(3 R, 4 R)-(-)-6$-methoxy-1-oxo-3-pentyl-3,4-dihydro- $1 \mathrm{H}$-isochromen-4-yl acetate (4), which exhibited an $\mathrm{AI} \mathrm{IC}_{50}$ of $1.6 \mu \mathrm{M}$ and was isolated from the Brazilian terrestrial plant Xyris pterygoblephara [17]. The quinolone alkaloid casimiroin (1) was originally isolated from Casimiroa edulis and found to inhibit both 7,12-dimethylbenz[a]anthracene (DMBA)-induced mutagenicity in Salmonella typhimurium and alveolar lesions in a mouse mammary gland organ culture ex vivo model (MMOC) [18]. In the course of follow-up synthetic and medicinal chemistry experiments, casimiroin was found to strongly inhibit aromatase $\left(\mathrm{IC}_{50} 3.9 \mu \mathrm{M}\right)$ [19]. Furthermore, several analogues of casimiroin also exhibited potent AI activity using the DBF fluoromet- 
Table 2 Natural product compounds active against aromatase in cellular and in vivo assaysa

\begin{tabular}{|c|c|c|c|c|c|}
\hline Compound Code & Source & Assay Type & Activity & & Ref. \\
\hline \multicolumn{6}{|l|}{ Alkaloid } \\
\hline 25 & Coptis japonicab & MCF-7 cells & active & synergy w/fulvestrant & [24] \\
\hline \multicolumn{6}{|l|}{ Flavonoids } \\
\hline \multicolumn{6}{|l|}{ Chalcone } \\
\hline 9 & Glycyrrhiza glabrab & MCF-7aro cells & 3 & $\mu \mathrm{M} \mathrm{K}_{\mathrm{i}}$ & [9] \\
\hline 9 & Glycyrrhiza glabrab & xenograft mouse & deterred & growth & [9] \\
\hline \multicolumn{6}{|l|}{ Catechin } \\
\hline 26 & Camellia sinensis ${ }^{\mathrm{b}}$ & CaSki cells & 76 & $\%$ reduction in mRNA expression & [26] \\
\hline 26 & Camellia sinensis $^{\mathrm{b}}$ & HeLa cells & 90 & $\%$ reduction in mRNA expression & [26] \\
\hline \multicolumn{6}{|l|}{ Isoflavones } \\
\hline 19 & Trifolium pratense $e^{\mathrm{b}}$ & MCF-7aro cells & 8 & $\mu \mathrm{MIC} \mathrm{C}_{50}$ & [10] \\
\hline 19 & Trifolium pratense $\mathrm{b}^{\mathrm{b}}$ & MCF-7aro cells & 10.8 & $\mu \mathrm{M} \mathrm{K}_{\mathrm{i}}$ & [10] \\
\hline 27 & Glycine max & HepG2 cells & induced & expression at $1 \mu \mathrm{M}$ & [27] \\
\hline 27 & Glycine max ${ }^{c}$ & zebrafish & induced & expression of aro-B gene & [28] \\
\hline \multicolumn{6}{|l|}{ Peptide } \\
\hline 28 & Brassaiopsis glomerulata & SK-BR-3 cells & 33.3 & PCA at $50 \mu \mathrm{M}$ & [14] \\
\hline \multicolumn{6}{|l|}{ Terpenoid } \\
\hline 29 & Cannabis sativa & MCF-7 cells ${ }^{d}$ & elevated & growth using $\mathrm{Al}$ & [29] \\
\hline 30 & Brassaiopsis glomerulata & SK-BR-3 cells & 21.8 & PCA at $50 \mu \mathrm{M}$ & [14] \\
\hline \multicolumn{6}{|l|}{ Xanthones } \\
\hline 22 & Garcinia mangostana & SK-BR-3 cells & 4.97 & $\mu \mathrm{MIC} \mathrm{I}_{50}$ & [12] \\
\hline 31 & Garcinia mangostana & SK-BR-3 cells & 32.3 & PCA at $50 \mu \mathrm{M}$ & [12] \\
\hline
\end{tabular}

a The structures of compounds $\mathbf{2 5 - 3 1}$ are shown in $\mathbf{~ F i g . ~ 2 ; ~}{ }^{\mathrm{b}}$ The source of the material in the literature reference is listed as commercial but this compound is traditionally isolated from a natural product source; ${ }^{\mathrm{C}}$ No data were provided regarding the source material used in this study; ${ }^{\mathrm{d}} \Delta^{9}$-THC induced

ric assay, with 5,6,8-trimethoxy-1,4-dimethylquinolin-2(1H)one exhibiting an $\mathrm{IC}_{50}$ in the low $\mathrm{nM}$ range (100 nM) [19].

Other strongly active natural compounds in the fluorometric assays have included commercially obtained apigenin $\left(16, K_{i}\right.$ $1.0 \mu \mathrm{M}$ ) [20], and two other flavonoids isolated from the resin of Prunus avium, namely, sakuranetin $\left(12, K_{i} 1.2 \mu \mathrm{M}\right)$, and tectochrysin $\left(17, K_{i} 2.1 \mu \mathrm{M}\right)$ [20]. All three of these compounds were tested further for antifungal activity, for which they exhibited no activity, under the experimental conditions used. However, these compounds were also tested against cytochrome P450 enzymes and found to inhibit CYP1A1 and CYP3A4, potentially indicative of broad, nonspecific activity, thus making them less ideal candidates for further preclinical development.

Three compounds were found to have moderate activity in the fluorometric AI assays. Baicalein $\left(18, K_{i} 5.1 \mu \mathrm{M}\right)$ [20] was obtained commercially and, as was reported above for compounds 12, 16, and 17, also inhibited the cytochrome P450 enzyme CYP3A4. Corynesidone A (5) was isolated from the terrestrial endophytic fungus Corynespora cassiicola L36 and observed to moderately inhibit aromatase with an $\mathrm{IC}_{50}$ value of $5.3 \mu \mathrm{M}$ [21]. All other isolates from this fungus were inactive against aromatase. Compound $\mathbf{5}$ was tested for cytotoxicity against a broad panel of cell types and demonstrated minimal cytotoxicity. Furthermore, corynesidone A exhibited strong antioxidant activity as measured using an oxygen radical absorbance capacity (ORAC) assay, but did not suppress the generation of TPA-induced superoxide anions in HL-60 cells [21]. Commercial myricetin (14), mentioned above during the discussion of liquiritigenin, also exhibited moderate AI activity with an $\mathrm{IC}_{50}$ of $10 \mu \mathrm{M}$ [16].

Four natural compounds were reported with weak AI activity in the fluorometric assays during the period covered by the present review. Commercially obtained gossypetin (15), also mentioned above during the discussion of liquiritigenin, exhibited weak AI activity with an $\mathrm{IC}_{50}$ of $11 \mu \mathrm{M}$ [16]. In the first reported instance of AI testing of a biflavonoid, the biflavanone, GB1 (5,7,4',3",5",7"-hep-

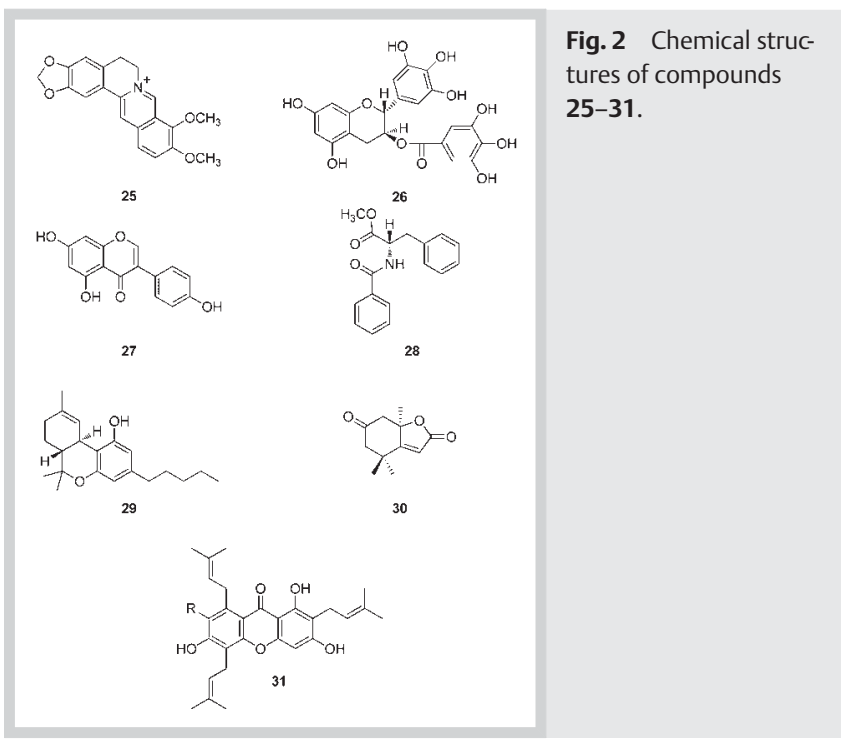

tahydroxy-3,8-biflavanone, 8), from the terrestrial plant Garcinia kola (bitter kola, a component in many African herbal medicines) was reported to have an $\mathrm{AI}^{\mathrm{IC}} \mathrm{C}_{50}$ of $11.3 \mu \mathrm{M}$ [22]. GB1 was also tested for $\alpha$-glucosidase inhibition, antiplasmodial activity, and cytotoxicity and found to also have considerable antimalarial activity with no cytotoxicity. Although the authors reported the inhibition of $\alpha$-glucosidase, the $\mathrm{IC}_{50}$ value determined in this study was as high as $900 \mu \mathrm{M}$, which would generally be considered inactive against this enzyme.

The final two compounds found to be weakly active in the fluorometric AI assay were two chromanones, monodictyochromes A (3, $\left.\mathrm{IC}_{50} 24.4 \mu \mathrm{M}\right)$ and $\mathrm{B}\left(2, \mathrm{IC}_{50} 16.5 \mu \mathrm{M}\right)$, isolated from the marine algicolous fungus Monodictys putredinis [23]. Monodictyochromes A and B were also tested against cytochrome P450 1A 
( $\mathrm{IC}_{50}$ values of 5.3 and $7.5 \mu \mathrm{M}$, respectively), and for induction of quinone reductase [concentrations to double activity ( $C D$ value) of 22.1 and $24.8 \mu \mathrm{M}$, respectively]. As in the case of previously mentioned compounds with several types of activity, these additional biological effects for monodictyochromes A and B may be indicative of broad, nonspecific action.

\section{Compounds active in cellular and in vivo Al assays}

Ten natural products were tested in cell-based in vitro and in in vivo testing during the reporting period of this review. Several of these compounds underwent substantial testing in numerous assay systems, presumably in an effort to pursue preclinical development. Flavonoids were again the most commonly tested class of compounds with four of the ten compounds tested falling into this class (two isoflavones, one chalcone, and one catechin). Two xanthones underwent screening in cellular AI assays, as well as two terpenoids, one alkaloid, and one peptide (OTable 2, Fig. 2). All of the active compounds tested in cellular and in vivo assays were either commercially purchased natural products or isolated from terrestrial plants. In most cases, each assay system was different and therefore findings from these reports will be discussed individually and grouped by compound.

The protoberberine alkaloid, berberine (25), was found to be the main active compound in the extract of Coptis japonica (part of the goldthread genus) and was subsequently purchased to afford sufficient material for further studies [24]. The research involved testing a combination of treatment with berberine and fulvestrant, a clinically utilized estrogen receptor antagonist that the authors indicated also acts as an aromatase antagonist. (However, this seems to be unsubstantiated from the reference used, since the most commonly accepted mechanism of action of fulvestrant is downregulation and degradion of the estrogen receptor [25]). Using the combination of berberine and fulvestrant, the authors found a synergistic inhibition of cell growth in MCF-7 cells, significantly different than both berberine and fulvestrant alone, which exhibited little to no inhibition.

Commercially purchased isoliquiritigenin (9) was found to be an active AI in three different test systems. In MCF-4aro cells (MCF-7 cells transfected with human CYP19), isoliquiritigenin was found to inhibit aromatase in a potent manner with a $K_{i}$ of $3 \mu \mathrm{M}$ [9]. They next tested isoliquiritigenin in a xenograft mouse model using athymic mice transplanted with MCF-7aro cells and found that the compound significantly suppressed xenograft growth (administered through feeding with doses of $0,50,150$, or $500 \mathrm{ppm}$ isoliquiritigenin supplementation). Finally, the effect of isoliquiritigenin was explored on specific aromatase promoters, namely, promoters I.3 and II, which are known to be breast-tissue specific, with the results indicating that the compound acts in a promoter-specific manner.

The most commonly reported catechin constituent of Camellia sinensis (green tea), (-)-epigallocatechin 3-gallate (EGCG, 26), was found to be active in cellular AI testing protocol, according to a recent report [26]. The regulation of aromatase by EGCG was studied in CaSki (HPV16 positive human cervical cancer) and HeLa (HPV18 positive human cervical cancer) cells, with this catechin derivative found to decrease mRNA expression in both cell types (after $12 \mathrm{~h} \mathrm{a}$ $76 \%$ reduction was found in CaSki cells; after $24 \mathrm{~h}$ a $90 \%$ reduction was found in HeLa cells). The authors suggested that these effects on cervical cancer cells could be indicative of the potential use of EGCG in cervical cancer chemoprevention.

Two common natural isoflavones, biochanin A (19) and genistein (27), were reported as having AI activity. The first, biochanin A, had previously been isolated from Trifolium pretense (red clover) and was obtained commercially for the studies in this report [10]. Compound 19 was reported to strongly inhibit aromatase in MCF7aro cells ( $\left.\mathrm{IC}_{50} 8 \mu \mathrm{M}, K_{i} 10.8 \mu \mathrm{M}\right)$. In addition, biochanin $\mathrm{A}$ was found to reduce mRNA expression in SK-BR-3 cells and was also found to act in a promoter-specific manner, upregulating breastspecific promoters I.3 and II, using luciferase reporter gene assays. Two separate studies have reported the aromatase activity of the Glycine max (soy) isoflavone, genistein (27). In the first study, genistein was obtained commercially and was found to induce aromatase activity in HepG2 cells using a concentration of $1 \mu \mathrm{M}$ [27]. Genistein was also found to induce promoter-specific aromatase mRNA expression, with significant increases in promoters I.3 and II [27], although the authors used HepG2 cells for this analysis, in which aromatase expression is generally believed to be regulated primarily by promoter I.4. Further experiments were performed with this isoflavonoid and demonstrated the activation of protein kinases PKC $\alpha$, P38, and ERK- $1 / 2$ and the activation of the transcriptional factor CREB. The inter-relationships between these protein kinases and the transcription factor with CYP19 promoter II was hypothesized. The second study relating to the AI activity of genistein involved the use of zebrafish as an in vivo model to test AI activity [28]. After finding that genistein binds and activates estrogen receptors $\alpha, \beta$, and $\gamma$, genistein was found also to induce expression of the aromatase- $B$ gene $(\operatorname{aro} B)$ in the brain of zebrafish, using an estrogen-receptor dependent pathway.

In work carried out by the present authors, the peptide, $\mathrm{N}$-benzoyl-L-phenylalanine methyl ester (28) was isolated from the Indonesian terrestrial plant Brassaiopsis glomerulata, and found to have weak AI activity in SK-BR-3 cells (33.3 PCA at $50 \mu \mathrm{M}$; no $\mathrm{IC}_{50}$ reported) [14]. Another isolate from $B$. glomerulata, the terpenoid (-)-dehydrololiolide (30), also showed AI activity in SK-BR-3 cells (21.8 PCA at $50 \mu \mathrm{M}$; no $\mathrm{IC}_{50}$ reported) [14]. One other terpenoid derivative has been ascribed with indirect activity on aromatase during the period covered by this review, namely, $\Delta^{9}$-tetrahydrocannabinol $\left(\Delta^{9}\right.$-THC, 29) isolated from Cannabis sativa (marijuana) [29]. $\Delta^{9}$-THC has been shown to cause MCF-7 cell proliferation and this growth was elevated by AIs, suggesting that aromatase plays a role in the $\Delta^{9}$-THC-induced proliferation of MCF-7 cells [29]. Finally, in our own work, two xanthones from the botanical dietary supplement Garcinia mangostana (mangosteen) were found to be active when tested against SK-BR-3 cells, including the strongly active $\gamma$-mangostin $\left(22, \mathrm{IC}_{50} 4.97 \mu \mathrm{M}\right)$ and the weakly active garcinone E (31, 32.3 PCA at $50 \mu \mathrm{M})$ [12]. Garconine D (23) and $\alpha$-mangostin (24) were inactive in this cellbased assay. The potent enzymatic and cellular AI activities of $\gamma$ mangostin, one of the most abundant isolates from the pericarp of Garcinia mangostana, make this a promising lead for further in vivo and preclinical studies to determine the potential role of mangosteen botanical dietary supplements in cancer chemoprevention and/or chemotherapy for postmenopausal women with hormone-dependent breast cancer.

\section{Comparison of the Most Recent and Previously Reported Natural Product Als \\ $\nabla$}

Several of the compounds that have been reported to inhibit aromatase during the past two years have also previously undergone testing for Al activity as reported in our previous review [7]. Apigenin (16) was found to be strongly active in microsomes in re- 
cent studies, which was also the case for much of the previous AI research on this compound, including noncellular and cellular tests. Myricetin (14) was also recently reported as a moderately active inhibitor of aromatase, consistent with previous literature reports on this compound. Biochanin A (19) was also recently found to be strongly active in cellular AI screening, whereas in previous studies the results for this compound were mixed, with some indicating inhibition of aromatase and others reporting inactivity. Isoliquiritigenin (9) and EGCG (26) were active in recent AI testing, and, as with biochanin A, these two compounds had previously been shown to have ambiguous aromatase activity. Two of the compounds reported herein as active, berberine (25) and genistein (27), have previously undergone AI testing and were found to be inactive in other assay systems. In the case of contradictory or ambiguous AI results for the same compounds, several possible variables should be considered, including the use of different assay systems (as mentioned above) and variations in the levels of compound purity, among others.

In comparing the levels of aromatase inhibition found in these more recent studies with those reported in the previous review, a decreased level of overall activity was noted. Several of most active natural product AIs found during the previous review are shown in 8 Fig. 3 [30-40]. In recent studies, three of the most active natural compounds in noncellular assays were found to have activity levels in the nanomolar range [liquiritigenin (10), 2-methoxy-5-acetoxyfuranogermacr-1(10)-en-6-one (20), and dehydroabietic acid (21)]. However, in previous studies, eight compounds (32-39) were reported with nanomolar AI activity in noncellular assays. The biggest difference in the activity of the recently reported natural product AIs was found in the cellular and in vivo assays where much lower levels of activity were reported than in previous years. Several previously reported compounds exhibited nanomolar activity in cell-based AI screens (16, 32, 33, 37,40 ) whereas all of the more recent reports are in the $\mu \mathrm{M}$ range [the three compounds considered strongly active in cell-based assay systems were $\gamma$-mangostin (22), isoliquiritigenin (9), and biochanin A (19)]. Interestingly, many of the more recent compounds have undergone substantially more molecular biology testing, resulting in reports of several active AIs that act on breast-tissue specific promoters.

\section{Conclusions and Future Directions \\ $\nabla$}

Natural product aromatase research has continued to produce exciting, potent aromatase inhibitory lead compounds that provide interesting new avenues of investigation. Several natural compounds have recently been identified to exhibit nanomolar levels of inhibition of the aromatase enzyme, both in noncellular and cellular AI assays, as well as exhibiting activity using in vivo mouse and zebrafish models. Many of these potent natural product AIs need further investigation to help determine their potential for preclinical and clinical development. Several of the compounds in this review could be the subject of extensive medicinal chemistry to modify the natural product scaffold, in the search for more potent AIs.

In the broader aromatase research arena, the search for more potent AIs is no longer the only consideration. As shown in the case of several of the recent natural product isolates described above, aromatase researchers have begun to explore the potential of identifying inhibitors that function in a promoter-specific manner, thus targeting the breast-specific aromatase promoters I.3

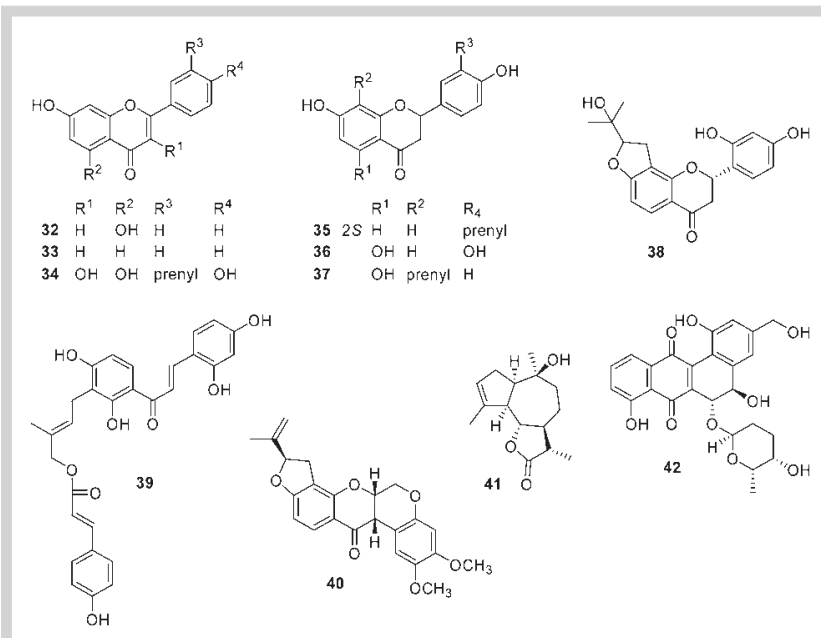

Fig. 3 Structures of strongly active aromatase inhibitors discussed in a previous review [7]. In cases above where absolute configuration is not indicated, no information was provided in the original literature.

and II $[41,42]$. Further studies are also utilizing new information about the aromatase enzyme X-ray structure to facilitate molecular modeling and docking studies [43]. Other research is exploring the use of combination treatments (e.g., aromatase inhibitors with endocrine disrupters) to circumvent breast cancer drug resistance [44]. Future investigations with natural product aromatase inhibitors will need to incorporate these types of multilateral studies to continue moving these exciting compounds from initial discovery to ultimate clinical utilization.

\section{Acknowledgements}

$\nabla$

Funding for research described in this review that was carried out at The Ohio State University was supported, in part, by The Ohio State University Comprehensive Cancer Center Molecular Carcinogenesis and Chemoprevention Program, awarded to A.D.K. We are grateful to Dr. Robert W. Brueggemeier, College of Pharmacy, The Ohio State University, for his collaboration in these studies, through NIH grant R01 CA73698 (to R. W. Brueggemeier). The collection of Brassaoipsis glomerulata studied by the authors was funded through program project P01 CA48112 (Principal Investigator, J.M. Pezzuto), awarded by NCI, NIH. This review was written while M.J.B. was supported through a $\mathrm{NIH}$ Fogarty International Center (FIC) International Research Scientist Development Award (IRSDA) K01 award (TW008002).

\section{Affiliations}

${ }^{1}$ Division of Medicinal Chemistry, Department of Pharmaceutical Sciences, School of Pharmacy, Storrs, CT, USA

${ }^{2}$ Center for Marine Biotechnology and Biomedicine, Scripps Institution of Oceanography, University of California San Diego, La Jolla, CA, USA

${ }^{3}$ Instituto de Investigaciones Científicas y Servicios de Alta Tecnología, Clayton, Panamá

${ }^{4}$ Smithsonian Tropical Research Institute, Ancón, Panamá

5 Division of Medicinal Chemistry and Pharmacognosy, College of Pharmacy, The Ohio State University, Columbus, $\mathrm{OH}$, USA 


\section{References}

1 Parkin DM, Fernandez LM. Use of statistics to assess the global burden of breast cancer. Breast J 2006; 12 (Suppl. 1): S70-S80

2 Igene $\mathrm{H}$. Global health inequalities and breast cancer: an impending public health problem for developing countries. Breast J 2008; 14: 428-434

3 Chlebowski R, CuzickJ, Amakye D, Bauerfeind I, Buzdar A, Chia S, Cutuli B, Linforth R, Maass N, Noguchi S, Robidoux A, Verma S, Hadji P. Clinical perspectives on the utility of aromatase inhibitors for the adjuvant treatment of breast cancer. Breast 2009; 18 (Suppl. 2): S1-S11

4 Gibson L, Lawrence D, Dawson C, Bliss J. Aromatase inhibitors for treatment of advanced breast cancer in postmenopausal women. Cochrane Database Syst Rev 2009: CD003370

5 Chlebowski RT, Anderson GL, Geller M, Col N. Coronary heart disease and stroke with aromatase inhibitor, tamoxifen, and menopausal hormone therapy use. Clin Breast Cancer 2006; 6 (Suppl. 2): S58-S64

6 Goss PE, Qi SL, Hu HQ Cheung AM. The effects of atamestane and toremifene alone and in combination compared with letrozole on bone, serum lipids and the uterus in an ovariectomized rat model. Breast Cancer Res Treat 2007; 103: 293-302

7 Balunas MJ, Su B, Brueggemeier RW, Kinghorn AD. Natural products as aromatase inhibitors. Anticancer Agents Med Chem 2008; 8: 646-682

8 Zhao J, Dasmahapatra AK, Khan SI, Khan IA. Anti-aromatase activity of the constituents from damiana (Turnera diffusa). J Ethnopharmacol 2008; 120: 387-393

9 Ye L, Gho WM, Chan FL, Chen S, Leung LK. Dietary administration of the licorice flavonoid isoliquiritigenin deters the growth of MCF-7 cells overexpressing aromatase. Int J Cancer 2009; 124: 1028-1036

10 Wang Y, Man Gho W, Chan FL, Chen S, Leung LK. The red clover (Trifolium pratense) isoflavone biochanin $\mathrm{A}$ inhibits aromatase activity and expression. Br J Nutr 2008; 99: 303-310

11 Su SL, Duan JA, Tang YP, Zhang X, Yu L, Jiang FR, Zhou W, Luo D, Ding AW. Isolation and biological activities of neomyrrhaol and other terpenes from the resin of Commiphora myrrha. Planta Med 2009; 75: 351-355

12 Balunas MJ, Su B, Brueggemeier RW, Kinghorn AD. Xanthones from the botanical dietary supplement mangosteen (Garcinia mangostana) with aromatase inhibitory activity. J Nat Prod 2008; 71: 1161-1166

13 Yang NY, Li K, Yang YF, Li YH. Aromatase inhibitory fatty acid derivatives from the pollen of Brassica campestris L. var. oleifera DC. J Asian Nat Prod Res 2009; 11: 132-137

14 Balunas MJ, Su B, Riswan S, Fong HHS, Brueggemeier RW, Pezzuto JM, Kinghorn $A D$. Isolation and characterization of aromatase inhibitors from Brassaiopsis glomerulata (Araliaceae). Phytochem Lett 2009; 2: 29-33

15 Balunas MJ, Su B, Landini S, Brueggemeier RW, Kinghorn AD. Interference by naturally occurring fatty acids in a noncellular enzyme-based aromatase bioassay. J Nat Prod 2006; 69: 700-703

16 Paoletta S, Steventon GB, Wildeboer D, Ehrman TM, Hylands PJ, Barlow $D J$. Screening of herbal constituents for aromatase inhibitory activity. Bioorg Med Chem 2008; 16: 8466-8470

17 Endringer DC, Guimaraes KG, Kondratyuk TP, Pezzuto JM, Braga FC. Selective inhibition of aromatase by a dihydroisocoumarin from Xyris pterygoblephara. J Nat Prod 2008; 71: 1082-1084

18 Ito A, Shamon LA, Yu B, Mata-Greenwood E, Lee SK, van Breemen RB, Mehta RG, Farnsworth NR, Fong HHS, Pezzuto JM, Kinghorn AD. Antimutagenic constituents of Casimiroa edulis with potential cancer chemopreventive activity. J Agric Food Chem 1998; 46: 3509-3516

19 Maiti A, Reddy PV, Sturdy M, Marler L, Pegan SD, Mesecar AD, Pezzuto JM, Cushman M. Synthesis of casimiroin and optimization of its quinone reductase 2 and aromatase inhibitory activities. J Med Chem 2009; 52: $1873-1884$

20 McNulty J, Nair JJ, Bollareddy E, Keskar K, Thorat A, Crankshaw DJ, Holloway $A C$, Khan G, Wright GD, Ejim L. Isolation of flavonoids from the heartwood and resin of Prunus avium and some preliminary biological investigations. Phytochemistry 2009; 70: 2040-2046

21 Chomcheon P, Wiyakrutta S, Sriubolmas N, Ngamrojanavanich N, Kengtong S, Mahidol C, Ruchirawat S, Kittakoop P. Aromatase inhibitory, radical scavenging, and antioxidant activities of depsidones and diaryl ethers from the endophytic fungus Corynespora cassiicola L36. Phytochemistry 2009; 70: 407-413
22 Antia BS, Pansanit A, Ekpa OD, Ekpe UJM, Chulabhorn, Kittakoop P. Alpha-glucosidase inhibitory, aromatase inhibitory, and antiplasmodial activities of a biflavonoid GB1 from Garcinia kola stem bark. Planta Med 2010; 76: 276-277

23 Pontius A, Krick A, Mesry R, Kehraus S, Foegen SE, Muller M, Klimo K, Gerhauser C, Konig GM. Monodictyochromes A and B, dimeric xanthone derivatives from the marine algicolous fungus Monodictys putredinis. J Nat Prod 2008; 71: 1793-1799

24 Liu J, He C, Zhou K, Wang J, Kang JX. Coptis extracts enhance the anticancer effect of estrogen receptor antagonists on human breast cancer cells. Biochem Biophys Res Commun 2009; 378: 174-178

25 Flemming J, Madarnas Y, Franek JA. Fulvestrant for systemic therapy of locally advanced or metastatic breast cancer in postmenopausal women: a systematic review. Breast Cancer Res Treat 2009; 115: 255-268

26 Qiao Y, Cao J, Xie L, Shi X. Cell growth inhibition and gene expression regulation by (-)-epigallocatechin-3-gallate in human cervical cancer cells. Arch Pharm Res 2009; 32: 1309-1315

27 Ye L, Chan MY, Leung LK. The soy isoflavone genistein induces estrogen synthesis in an extragonadal pathway. Mol Cell Endocrinol 2009; 302: 73-80

28 Sassi-Messai S, Gibert Y, Bernard L, Nishio S, Ferri Lagneau KF, Molina J, Andersson-Lendahl M, Benoit G, Balaguer P, Laudet $V$. The phytoestrogen genistein affects zebrafish development through two different pathways. PLoS One 2009; 4: e4935

29 Takeda S, Yamamoto I, Watanabe K. Modulation of $\Delta^{9}$-tetrahydrocannabinol-induced MCF-7 breast cancer cell growth by cyclooxygenase and aromatase. Toxicology 2009; 259: 25-32

30 Kellis Jr JT, Vickery LE. Inhibition of human estrogen synthetase (aromatase) by flavones. Science 1984; 225: 1032-1034

31 Le Bail JC, Champavier Y, Chulia AJ, Habrioux G. Effects of phytoestrogens on aromatase, $3 \beta$ - and $17 \beta$-hydroxysteroid dehydrogenase activities and human breast cancer cells. Life Sci 2000; 66: 1281-1291

32 Le Bail JC, Pouget C, Fagnere C, Basly JP, Chulia AJ, Habrioux G. Chalcones are potent inhibitors of aromatase and $17 \beta$-hydroxysteroid dehydrogenase activities. Life Sci 2001; 68: 751-761

33 Saarinen N, Joshi SC, Ahotupa M, Li X, Ammala J, Makela S, Santti R. No evidence for the in vivo activity of aromatase-inhibiting flavonoids. J Steroid Biochem Mol Biol 2001; 78: 231-239

34 Lee D, Bhat KPL, Fong HHS, Farnsworth NR, Pezzuto JM, Kinghorn AD. Aromatase inhibitors from Broussonetia papyrifera. J Nat Prod 2001; 64: 1286-1293

35 van Meeuwen JA, Nijmeijer S, Mutarapat T, Ruchirawat S, de Jong PC, Piersma AH, van den Berg M. Aromatase inhibition by synthetic lactones and flavonoids in human placental microsomes and breast fibroblasts - a comparative study. Toxicol Appl Pharmacol 2008; 228: 269273

36 Monteiro R, Becker H, Azevedo I, Calhau C. Effect of hop (Humulus lupulus L.) flavonoids on aromatase (estrogen synthase) activity. J Agric Food Chem 2006; 54: 2938-2943

37 Monteiro R, Faria A, Azevedo I, Calhau C. Modulation of breast cancer cell survival by aromatase inhibiting hop (Humulus lupulus L.) flavonoids. J Steroid Biochem Mol Biol 2007; 105: 124-130

38 Sanderson JT, Hordijk J, Denison MS, Springsteel MF, Nantz MH, van den Berg $M$. Induction and inhibition of aromatase (CYP19) activity by natural and synthetic flavonoid compounds in H295R human adrenocortical carcinoma cells. Toxicol Sci 2004; 82: 70-79

39 Blanco JG, Gil RR, Bocco JL, Meragelman TL, Genti-Raimondi S, Flury A Aromatase inhibition by an 11,13-dihydro derivative of a sesquiterpene lactone. J Pharmacol Exp Ther 2001; 297: 1099-1105

40 Kanamaru T, Nozaki YM, Masayuki M. TAN-1085 and its aglycon as angiogenesis and aromatase inhibitors and their manufacture with Streptomyces species. Japanese Patent JP02-289532; 1990

41 Santen RJ, Brodie H, Simpson ER, Siiteri PK, Brodie A. History of aromatase: saga of an important biological mediator and therapeutic target. Endocr Rev 2009; 30: 343-375

42 Bulun SE, Lin Z, Zhao H, Lu M, Amin S, Reierstad S, Chen D. Regulation of aromatase expression in breast cancer tissue. Ann NY Acad Sci 2009; 1155: 121-131

43 Ghosh D, Griswold J, Erman M, Pangborn W. X-ray structure of human aromatase reveals an androgen-specific active site. J Steroid Biochem Mol Biol 2010; 118: 197-202

44 Wong ST. Emerging treatment combinations: integrating therapy into clinical practice. Am J Health Syst Pharm 2009; 66: S9-S14 